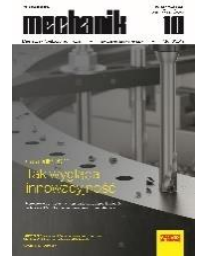

How to cite this article:

Authors: Krzysztof Ciecieląg, Kazimierz Zaleski, Krzysztof Kęcik

Title of article: „The influence of milling parameters on the surface roughness of glass and carbon fiber reinforced plastics"

Mechanik, No. 10 (2019)

DOI: https://doi.org/10.17814/mechanik.2019.10.84

\title{
The influence of milling parameters on the surface roughness of glass and carbon fiber reinforced plastics
}

\author{
KRZYSZTOF CIECIELĄG \\ KAZIMIERZ ZALESKI \\ KRZYSZTOF KĘCIK *
}

Dr inż. Krzysztof Ciecieląg, k.ciecielag@pollub.pl, https://orcid.org/0000-0003-1336-0438 - Katedra Podstaw Inżynierii Produkcji, Wydział Mechaniczny, Politechnika Lubelska, Lublin, Polska

Dr hab. inż. Kazimierz Zaleski, prof. PL, k.zaleski@pollub.pl, https://orcid.org/0000-0002-3757-3676 - Katedra Podstaw Inżynierii Produkcji, Wydział Mechaniczny, Politechnika Lubelska, Lublin, Polska

Dr hab. inż. Krzyszof Kęcik, prof. PL, k.kecik@pollub.pl, https://orcid.org/0000-0001-8293-6977 - Katedra Mechaniki Stosowanej, Wydział Mechaniczny, Politechnika Lubelska, Lublin, Polska

In this paper, the impact of milling process parameters on the roughness of surface of glass and carbon fiber reinforced plastics was analyzed. The influence of feed per tooth, cutting speed and depth of cut on selected surface roughness parameters was determined. It was found that the surface roughness after milling carbon fiber reinforced plastics was greater compared to the surface of glass fiber reinforced plastics.

\section{KEYWORDS: polymer composites, milling, surface roughness}

\section{Introduction}

Roughness is one of the main factors determining the geometric structure of a surface. Of the many roughness parameters, the $R a$ parameter and $R z$ parameter (the largest height of the roughness profile) are commonly used in process monitoring [1]. In addition, the Rsk parameter associated with surface wear and friction was used [2]. However, based on the value of the $R k u$ parameter, one can conclude about the occurrence of surface defects.

Polymer composites are milled as a finishing machining in order to remove the allowance generated at the manufacturing stage [9]. When choosing the milling parameters, the material structure, orientation and type of fibers as well as the expected surface roughness should be taken into account.

Research works related to the machining of polymer composites with glass fibers focus on the analysis of cutting speed in the range of: $60 \div 250 \mathrm{~m} / \mathrm{min}[5,10]$, feed per tooth: $0.01 \div 0.2 \mathrm{~mm} /$ blade [5] and depth of cut: $0.4 \div 2$ $\mathrm{mm}[3,10]$. When machining composites with carbon fibers, cutting speeds are used: $20 \div 250 \mathrm{~m} / \mathrm{min}[4-6,8]$, feed per tooth: $0.01 \div 0.5 \mathrm{~mm} /$ cutting edge $[5-7,10]$ and cutting depth: $0.1 \div 4 \mathrm{~mm}[6-8,10]$.

Previous work on milling polymer composites has shown that cutting parameters affect the surface roughness in composites with carbon fibers [3]. Variety of results and variables affecting machining quality necessitates the need to examine processes and machinability indicators.

The aim of the study was to determine the impact of speed, feed per tooth and depth of cut during milling of polymer composites with glass and carbon fibers on surface roughness.

\section{Research methodology}

The subject of the research were polymer composites with GFRP glass fibers (Fig. 1a) and carbon CFRP (Fig. $1 b$ ) impregnated with epoxy resin, in the form of plate with dimensions of $300 \mathrm{~mm} \times 300 \mathrm{~mm} \times 15 \mathrm{~mm}$, made of 50 layers of prepregs with alternating fiber arrangement. 

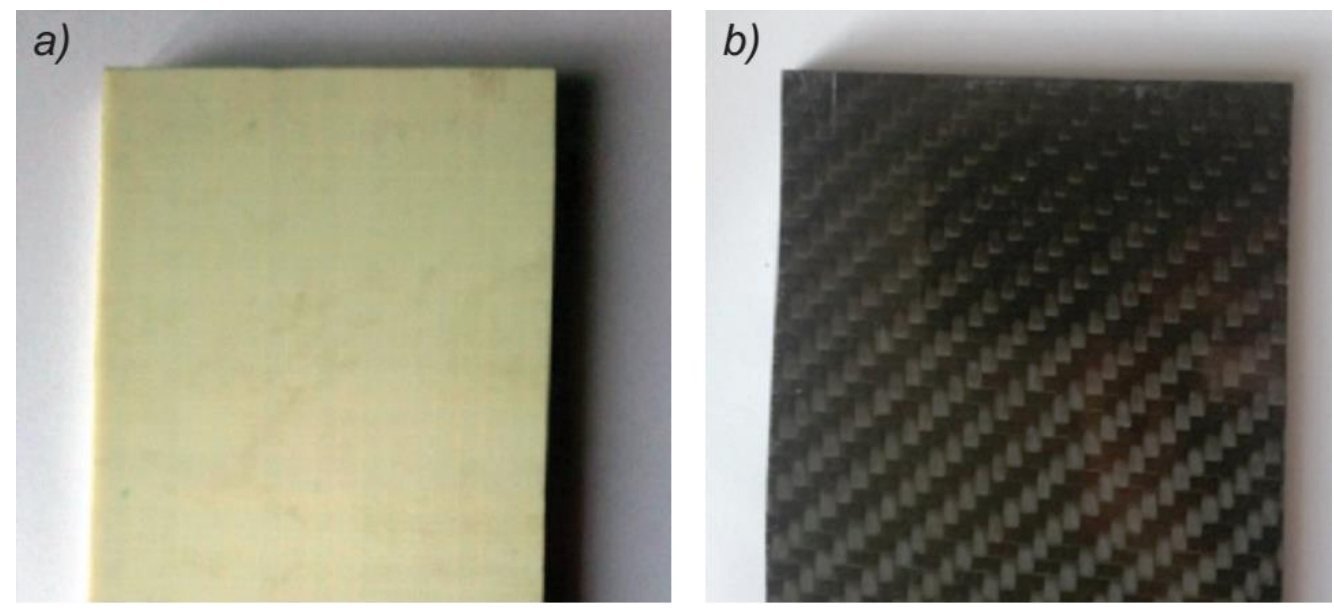

Fig. 1. Processed materials: $a$ ) plate with glass fibers, $b$ ) plate with carbon fibers

The milling machining process was carried out on a vertical machining center using milling cutters with a diameter of $\varnothing 20 \mathrm{~mm}$, with replaceable PCD coated inserts intended for machining composite materials, with a corner radius of $0.4 \mathrm{~mm}$ and a clearance angle of $15^{\circ}$. The table presents milling parameters adopted in the research.

TABLE. Milling parameters of polymer composites

\begin{tabular}{|l|c|c|c|}
\hline & $v_{\mathrm{c}}[\mathrm{m} / \mathrm{min}]$ & $f_{\mathrm{z}}[\mathrm{mm} /$ blade $]$ & $a_{\mathrm{p}}[\mathrm{mm}]$ \\
\hline 1 & 50 & 0.2 & 1 \\
\hline 2 & 100 & 0.2 & 1 \\
\hline 3 & 250 & 0.2 & 1 \\
\hline 4 & 350 & 0.2 & 1 \\
\hline 5 & 500 & 0.2 & 1 \\
\hline 6 & 250 & 0.04 & 1 \\
\hline 7 & 250 & 0.1 & 1 \\
\hline 8 & 250 & 0.4 & 1 \\
\hline 9 & 250 & 0.6 & 1 \\
\hline 10 & 250 & 0.2 & 0.5 \\
\hline 11 & 250 & 0.2 & 1.5 \\
\hline 12 & 250 & 0.2 & 2 \\
\hline 13 & 250 & 0.2 & 2.5 \\
\hline
\end{tabular}

Each of the tested roughness parameters was measured eight times at different places on the surface of the materials. The smallest and largest measured values were discarded. and then mean values and standard deviations were calculated.

\section{Results}

On the basis of determined average values: graphs were made of the relationship between milling parameters and roughness parameters. Figs. 2-5 show the effect of cutting speed on roughness parameters: $R a, R z, R s k$ and $R k u$.

With an increase in cutting speed in the range from $50 \mathrm{~m} / \mathrm{min}$ to $500 \mathrm{~m} / \mathrm{min}$ - the roughness parameter $R a$ decreased by $23 \%$ for GFRP and $46 \%$ for CFRP (Fig. 2). the roughness parameter $R z$ decreased by $15 \%$ for GFRP and by $42 \%$ for CFRP (Fig. 3) and the Rsk parameter increased by $44 \%$ for GFRP and by $28 \%$ for CFRP (Fig. 4). The highest value of the $R k u$ parameter was obtained for a cutting speed of $100 \div 250 \mathrm{~m} / \mathrm{min}$ (Fig. 5).

Figs. 6-9 show the influence of feed per tooth on roughness parameters: $R a, R z, R s k$ and $R k u$. With the increase in feed: the $R a$ parameter increased by $46 \%$ for GFRP and by $84 \%$ for CFRP (Fig. 6 ). $R z$ parameter by $15 \%$ for GFRP and by $70 \%$ for CFRP (Fig. 7). as well as the Rku parameter by $23 \%$ for GFRP and $72 \%$ for CFRP (Fig. 9). The Rsk parameter decreased by $25 \%$ for GFRP and by $88 \%$ for CFRP (Fig. 8). 


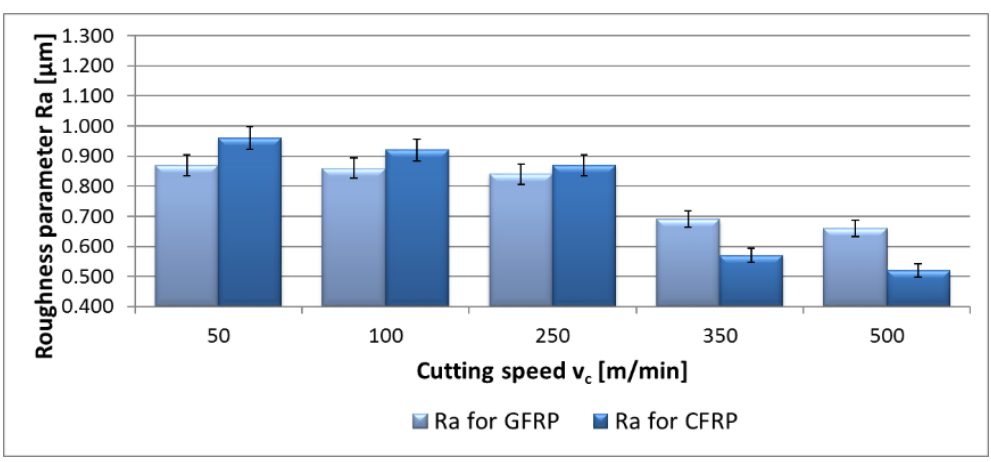

Fig. 2. Relationship between cutting speed and Ra parameter

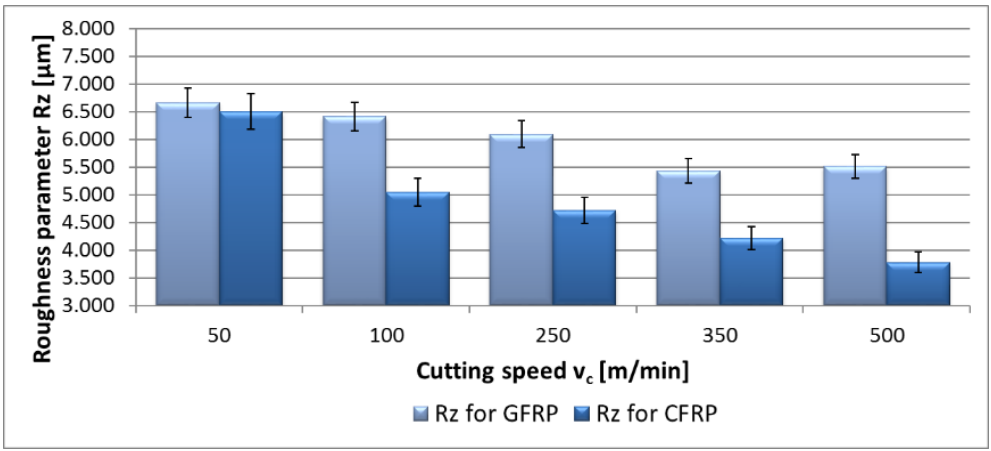

Fig. 3. Relationship between cutting speed and Rz parameter

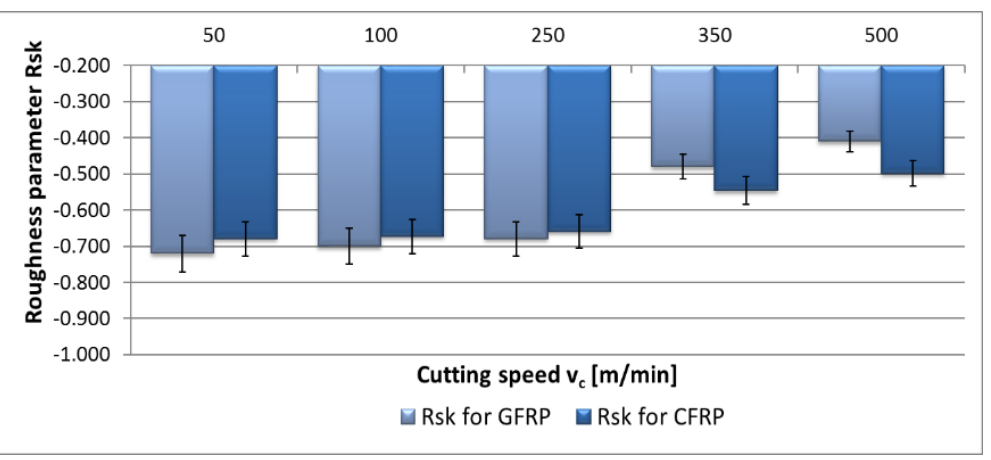

Fig. 4. Relationship between cutting speed and Rsk parameter

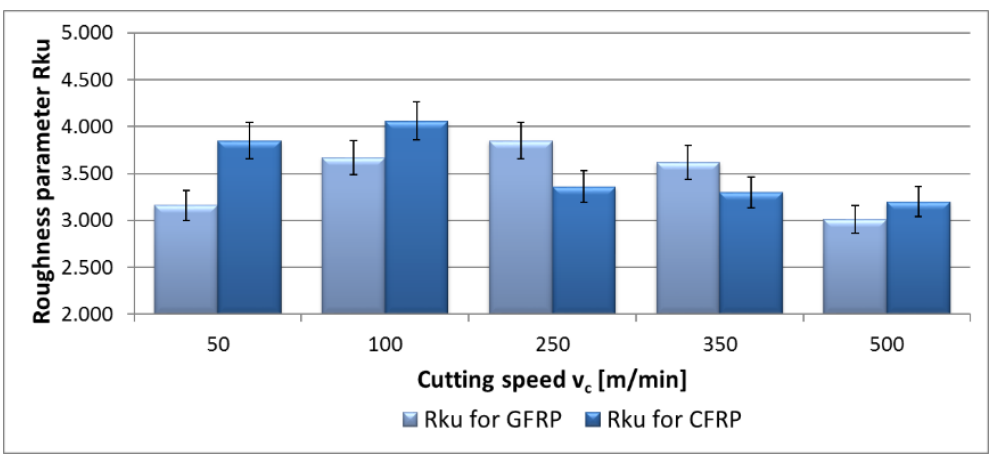

Fig. 5. Relationship between cutting speed and Rku parameter 


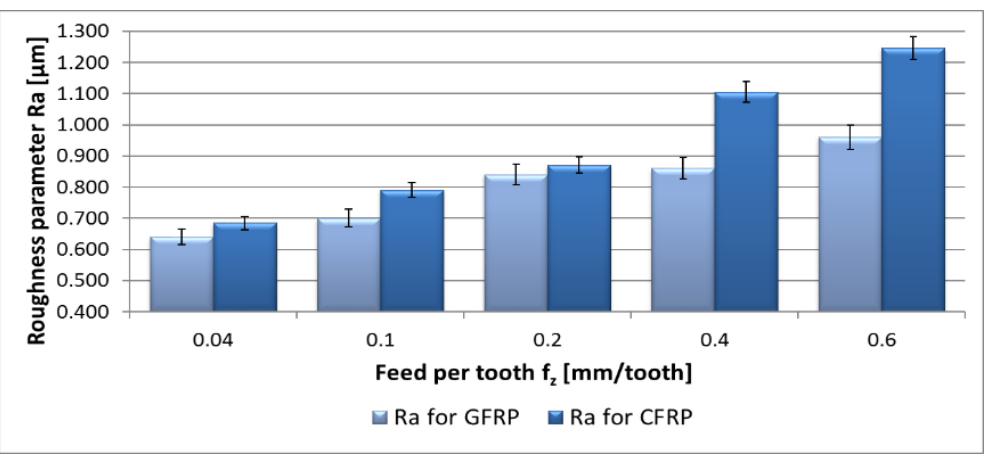

Fig. 6. Relationship between feed per tooth and Ra parameter

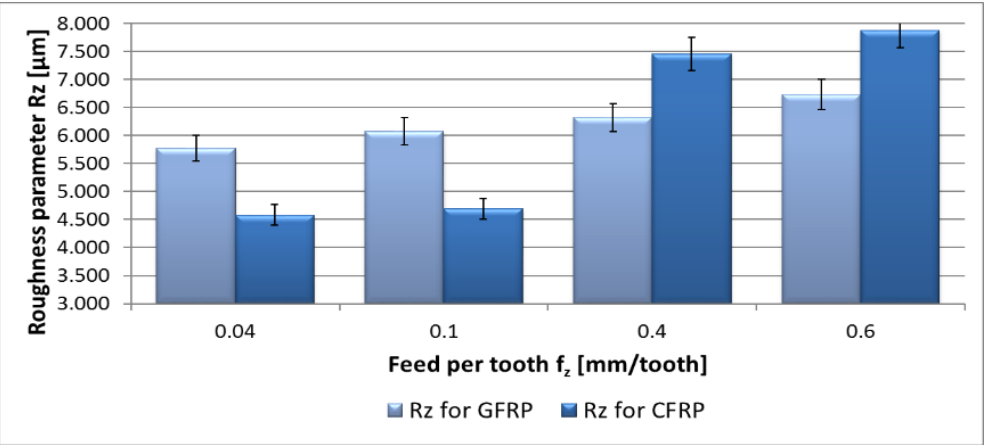

Fig. 7. Relationship between feed per tooth and Rz parameter

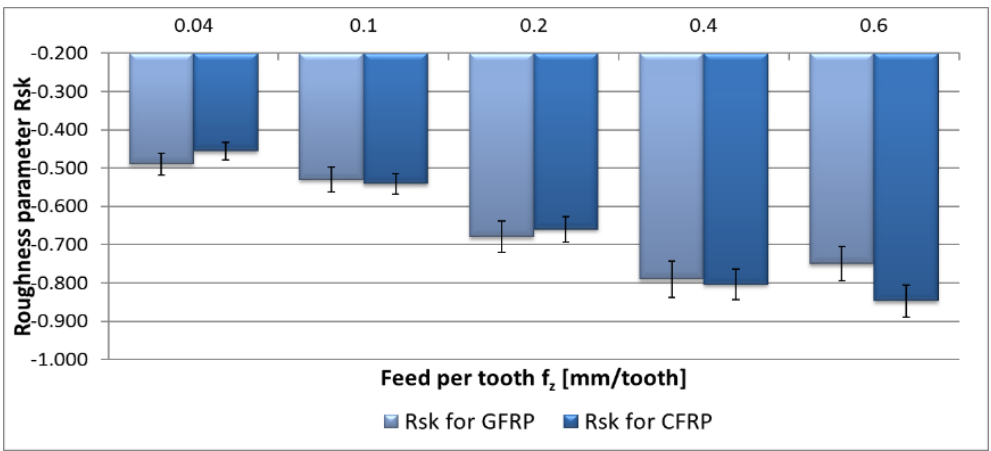

Fig. 8. Relationship between feed per tooth and Rsk parameter

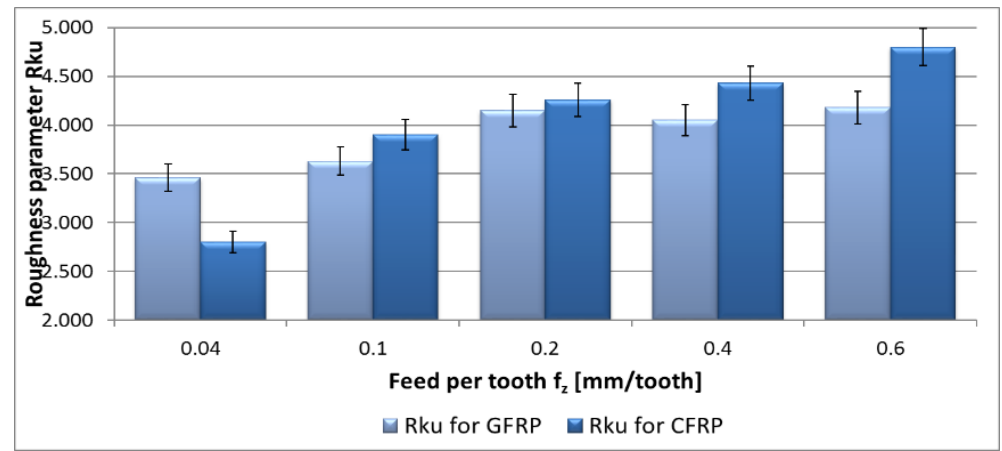

Fig. 9. Relationship between feed per tooth and Rku parameter

Figs. 10-13 show the effect of cutting depth on roughness parameters: Ra, Rz, Rsk and Rku. There were no significant changes in the values of roughness parameters as the cutting depth increased. 


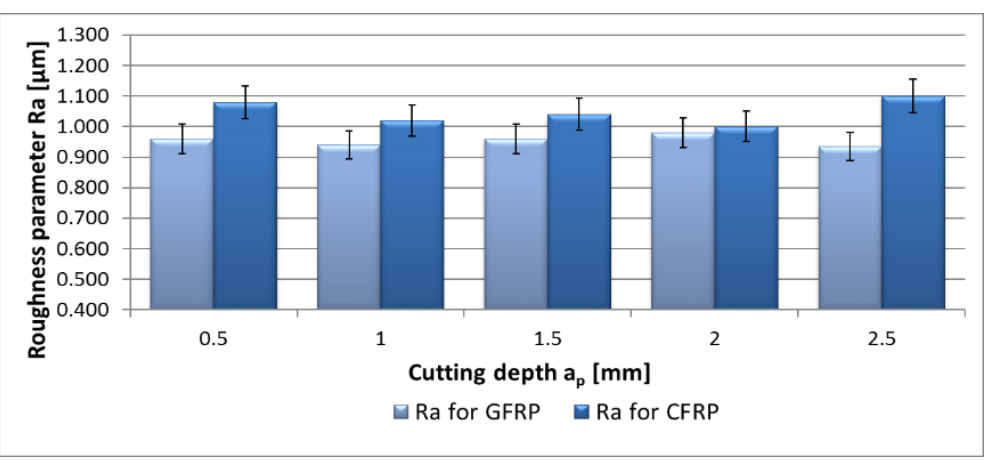

Fig. 10. Relationship between cutting depth and Ra parameter

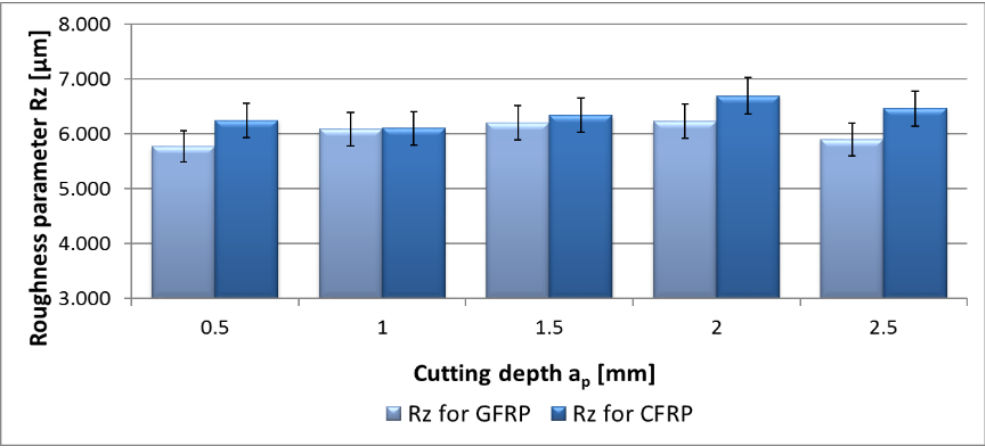

Fig. 11. Relationship between cutting depth and Rz parameter

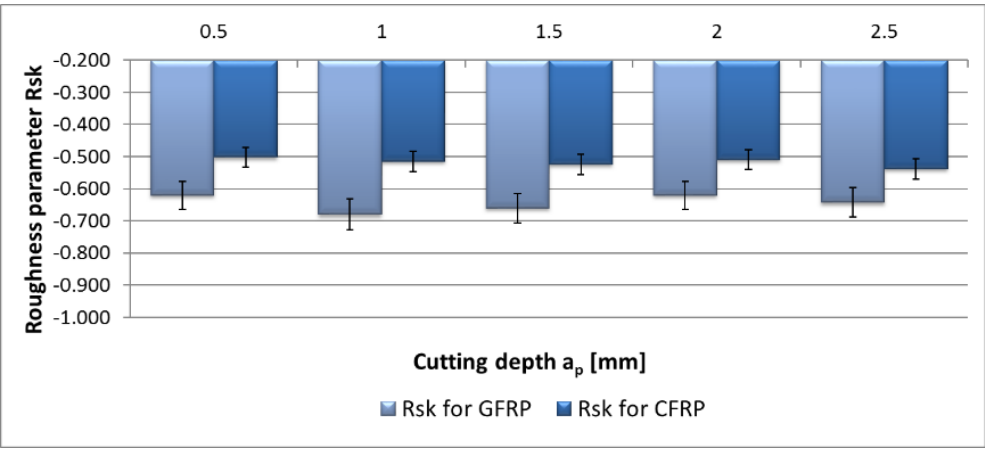

Fig. 12. Relationship between cutting depth and Rsk parameter

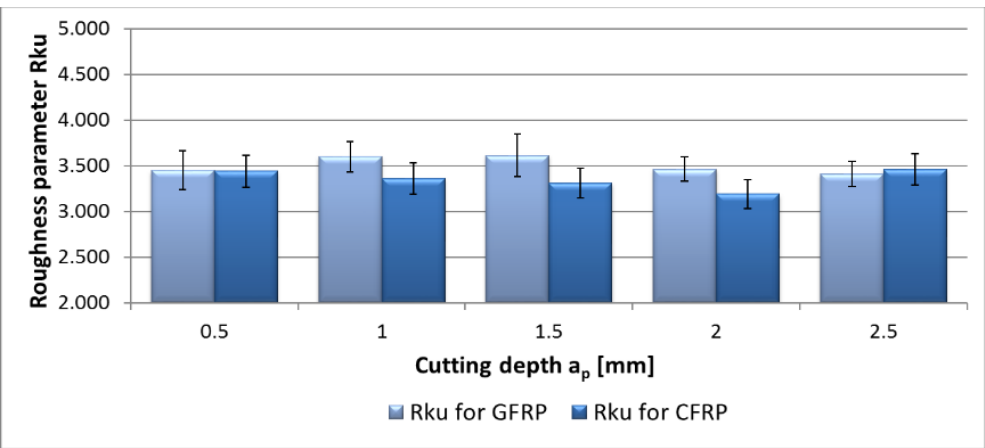

Fig. 13. Relationship between cutting depth and Rku parameter

\section{Summary}

Based on the results of the research- it can be stated that:

- an increase in cutting speed causes a decrease in the value of roughness parameters $R a, R z, R k u$ and an increase in the Rsk parameter: which indicates better surface quality after machining at a higher cutting speed; 
- an increase in feed per tooth increases the roughness parameters $R a, R z$ and $R k u$ as well as a decrease in the Rsk parameter;

- changing the cutting depth does not significantly change the surface roughness parameters;

- due to the possibility of surface defects- low or high cutting speeds (smallest parameter $R k u$ ) should be used;

- a significant increase in the $R k u$ parameter as the feed increases the greater likelihood of surface defects after high feed of milling;

- CFRP material is more susceptible to changes in surface roughness caused by an increase in feed and cutting speed compared to the GFRP composite.

\section{REFERENCES}

[1] Wieczorowski M., Cellary A., Chajda J. „Przewodnik po pomiarach nierówności powierzchni czyli o chropowatości i nie tylko”. Poznań: Wydawnictwo Politechniki Poznańskiej, 2003.

[2] Grzesik W. „Wpływ topografii powierzchni na właściwości eksploatacyjne części maszyn”. Mechanik. 8-9 (2015): 587-592. DOI: 10.17814/mechanik.2015.8-9.493.

[3] Azmi A.I., Lin R.J.T., Bhattacharyya D. "Machinability study of glass fibre reinforced polymer composites during end milling". The International Journal of Advanced Manufacturing Technology. 64 (2013): 247-261. DOI: 10.1007/s00170-012-4006-6.

[4] Davim J.P., Reis P. "Damage and dimensional precision on milling carbon fiber-reinforced plastics using design experiments". Journal of Materials Processing Technology, 160 (2005): 160-167. https://doi.org/10.1016/j.jmatprotec.2004.06.003.

[5] Ghidossi P., El Mansori M., Pierron F. "Edge machining effects on the failure of polymer matrix composite coupons". Composites: Part A. 35, (2004): 989-999. https://doi.org/10.1016/j.compositesa.2004.01.015.

[6] Hosokawa A., Hirose N., Ueda T., Furumoto T. "High quality machining of CFRP with high helix end mill”. CIRP Annals, Manufacturing Technology. 63 (2014): 89-92. https://doi.org/10.1016/j.cirp.2014.03.084.

[7] Karpat Y., Bahtiyar O., Deger B. "Mechanistic force modeling for milling of unidirectional carbon fiber reinforced polymer laminates". International Journal of Machine Tools and Manufacture. 56 (2012): 79-93. https://doi.org/10.1016/j.ijmachtools.2012.01.001.

[8] Pecat O., Rentsch R., Brinksmeier E. "Influence of milling process parameters on the surface integrity of CFRP”. Procedia CIRP. 1 (2012): 466-470. https://doi.org/10.1016/j.procir.2012.04.083.

[9] Puw H.Y., Hocheng H. "Machinability test of carbon fiber reinforced plastics in milling". Materials and Manufacturing Processes. 8, 6 (1993): 717-729. https://doi.org/10.1080/10426919308934875.

[10] Teicher U., Rosenbaum T., Nestler A., Brosius A., "Characterization of the surface roughness of milled carbon fiber reinforced plastics structures". Procedia CIRP. 66 (2017): 199-203. https://doi.org/10.1016/j.procir.2017.03.282. 